\title{
Environmental impacts of cage culture in Lake Victoria: the case of Shirati Bay-Sota, Tanzania
}

\author{
Benedicto Boniphace Kashindye ${ }^{1 *}$, P. Nsinda ${ }^{2}$, R. Kayanda', G. W. Ngupula ${ }^{1}$, C. A. Mashafi ${ }^{1}$ and C. N. Ezekiel ${ }^{1}$
}

${ }^{*}$ Correspondence:

bkashindye@yahoo.com

${ }^{1}$ Tanzania Fisheries Research Institute (TAFIRI), P. O.

Box 475, Mwanza, Tanzania

Full list of author information

is available at the end of the article

\begin{abstract}
The experimental cage culture was conducted at Shirati bay, Lake Victoria from February to August 2013, to investigate the impacts of the small scale cage culture on the environment. Three locations along the cages, at the intermediate and one in the offshore (control) were sampled for water quality parameters, phytoplankton and macro invertebrates. A notable increase in nutrient concentration was observed after the set of cages among the stations. However $\mathrm{DO}, \mathrm{pH}$, and water transparency showed no major changes and was within the recommended ranges. Cyanophytes an indicator of inorganic pollution dominated before and after the set of cages, an increase in phytoplankton numerical abundance was observed after stocking of fish in cages. In addition there was an increase in the invertebrate community especially bivalves and gastropods. In conclusion we found no consistent environmental change caused by cage culture, and therefore it can be allowed in Lake Victoria, Tanzania part, with close monitoring of its impacts.
\end{abstract}

Keywords: Cage culture, Nutrient enrichment, Water quality, Waste food

\section{Background}

Fish farming in cages though is the most common technology in marine waters, practiced mostly by developed countries (i.e. Norway, Germany, Netherlands) and most of the developing countries of South East Asia (i.e. China, Vietnam, Philippines, and Thailand). In most African countries it seems to be a new technology (FAO 2004). In East Africa for some extent, cage farming of Nile tilapia has been practiced for a while now by the Source of the Nile (S.O.N), a private company based in Uganda.

Declining catches of fish around Lake Victoria basin and growing demand for protein from fish has ultimately resulted into strengthening strategies of boosting aquaculture productions by the governments of the East African countries so as to fill the growing gap of productions from capture fisheries. The Lake Victoria being such large attracts cage farming unto it for increased fish yields. So far cage fish farming is not allowed by law in the Tanzanian waters of Lake Victoria on the fear of environmental pollution and other associated ecological effects. However, the demand for environmental impact assessment study for the positive consideration of cage farming in the Lake Victoria waters has been an issue of concern by the government of Tanzania for a decade now.

\section{望 Springer}

(c) 2015 Kashindye et al. This article is distributed under the terms of the Creative Commons Attribution 4.0 International License (http://creativecommons.org/licenses/by/4.0/), which permits unrestricted use, distribution, and reproduction in any medium, provided you give appropriate credit to the original author(s) and the source, provide a link to the Creative Commons license, and indicate if changes were made. 
The Association for Strengthening Agricultural Research in East and Central Africa (ASARECA) project in promoting the use of reservoirs and lakes to practice small scale cage culture in cooperation with Tanzania Fisheries Research Institute (TAFIRI), the practice is currently expanding.

Generally growing fish in cages may have negative environmental consequences. The possible consequences associated with cage culture farming include discharge of particulate and dissolved nutrients through uneaten waste feed, fecal matter, and excretory products (Masser 2008). And, this may negatively impact the environment by causing anoxic conditions in sediments (due to organic enrichments) underlying the cages, thus changing the invertebrates abundances and compositions (Ngupula and Kayanda 2010). In addition it may cause eutrophication due to nutrient enrichment of the water column (Ngupula et al. 2012). Furthermore farmed fish may escape and interact with other fish in the wild the results of which is the spread diseases and parasites. All these may result into ecological simplicity, and decrease in genetic diversity (due to genetic dilution) and increased mortality of the wild stocks (due to transferred diseases).

Since ASARECA project is critical in the development and promotion of cage aquaculture technology in Tanzania, a research component was designed and incorporated with the objective of checking on the feasibility of cage farming and the associated negative environmental issues.

Therefore, the present paper was aimed for testing the feasibility of cage farming in Lake Victoria waters and assesses some possible associated environmental consequences.

\section{Methods}

\section{Study site}

The sampling station (Shirati bay) where this study was carried out is shown in Fig. 1. Data was collected from February to August 2013. Shirati bay is approximated to have the surface area of $14 \mathrm{~km}^{2}$, the mean depth is $10 \mathrm{~m}$. The deepest part of the bay is $15 \mathrm{~m}$. Before deployment of cages for fish culture the environmental status of Shirati bay was assessed for its suitability for fish farming, including determining direction of the current. The current was flowing from South West to North East in the range of 4-6 knots in the morning and 7-10 knots in the afternoon. The cages were set at $1^{\circ} 8^{\prime} 3.78^{\prime \prime} \mathrm{S}$ and $33^{\circ} 59^{\prime} 45.46^{\prime \prime} \mathrm{N}$ near to the shore of, Shirati Bay, about $75 \mathrm{~m}$ offshore.

Nine cages of $2 \mathrm{~m} \times 2 \mathrm{~m} \times 2 \mathrm{~m}$ which were made of multifilament nets were set for Nile tilapia cage culture trials in February 2013. In order to detect the impact of fish cage culture in Shirati bay, three sampling locations close to each other along the cages, an intermediate site (50 m away from the cages) and a control site (located in south offshore waters $500 \mathrm{~m}$ away from the cages) were randomly selected and marked using a GARMIN Global Positioning System (GPS). The mean depth of the area where the cages were set was $7.0 \pm 0.0 \mathrm{~m}$, the intermediate station had the mean depth of $11.0 \pm 0.0 \mathrm{~m}$ and the control had the mean depth of $12.0 \pm 0.0 \mathrm{~m}$. The cages were stocked with a total of 7041 fish of mean weights of $18.0 \pm 2.1,19.9 \pm 14.7$, and $18.5 \pm 8.0 \mathrm{~g}$ in triplicates at stocking densities of 70,100 , and $130 \mathrm{fish} / \mathrm{m}^{3}$ respectively. The trials lasted for the period of 6 months. The fish were fed with TAF1 and Ugachick feeds both of $25 \%$ crude protein. TAF1 feed is semi floating formulated feeds from locally available feeds, while 


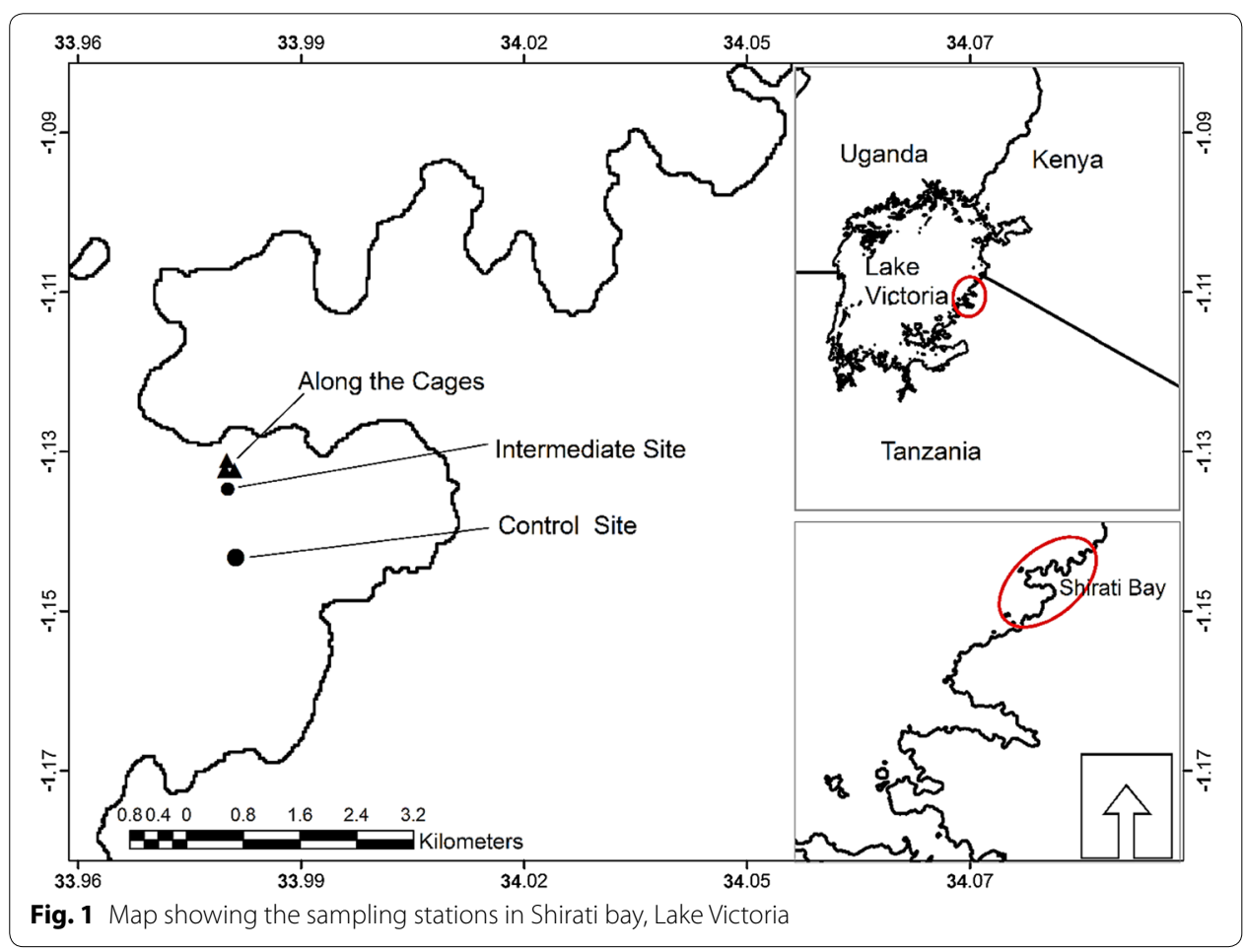

Ugachick is commercial floating feeds imported from Uganda. The fish were fed at the feeding ration of $5 \%$ per body weight three times a day at 1000, 1300 and 1600 h East African time.

\section{Water chemistry}

Physicochemical parameters such as $\mathrm{pH}$, DO, water temperature, Secchi depth and total depth were measured on weekly basis at $0900 \mathrm{~h}$ during the whole sampling period. In situ measurement of $\mathrm{pH}$ and $\mathrm{DO}$ was done using a calibrated portable Oxygen- $\mathrm{pH}$ probe (Model: 9024). pH and DO were measured for surface middle and bottom, the values obtained were averaged over the water column and calculated on monthly basis. Water transparency (m) was measured by a standard Secchi disk of $20 \mathrm{~cm}$ diameter, with quadrants painted in black and white. The Secchi depth was calculated as the average of the depth at disappearance and that of reappearance of the disk in water. Total depth (m) was measured by a graduated rope.

Water samples for the analysis of nutrients (Ammonia, Soluble Reactive Phosphorus, Total Nitrogen, Nitrites, Nitrates, Total phosphorus and Chlorophyll $a$ ) was taken on monthly basis for 3 months using a 1-1 Van Dorn water sampler. Samples were collected for surface, mid, and bottom (about $0.4 \mathrm{~m}$ above the lake bottom and below the surface water) and mixed over the water column to make a composite sample per each sampling location. Samples were then preserved on ice pending analysis in the laboratory. Standard methods were used to analyze key nutrients, Total phosphorus (TP) was analyzed by Persulfate digestion method, Soluble reactive phosphorous, (SRP) by Ascorbic acid method, nitrate-nitrogen $\left(\mathrm{NO}_{3}-\mathrm{N}\right)$ by Cadmium reduction method, Nitrite 
Nitrogen by Colorimetric methods and Chlorophyll $a$ concentrations by ethanol extraction method. Concentrations of these nutrients and Chlorophyll $a$ were determined by spectrophotometry.

\section{Biological samples}

Macro-invertebrates and phytoplankton diversity and abundance were sampled before stocking of fish and the start of feeding experiments in cages and 2 weeks before the end of the experiment.

Macro-invertebrate samples were obtained using a $384 \mathrm{~cm}^{2}$ Eckman grab sampler. Two hauls of the grab sampler was mixed to make one composite sample. A net of $500 \mu \mathrm{m}$ was used to separate organisms from the sediments. The collected samples were preserved in $4 \%$ formalin. In the laboratory the macro-invertebrates were identified and analyzed according to Brown (1994) and Mandahl-Barth (1958, 1973, 1988).

Plankton net of $10 \mu \mathrm{m}$ mesh size was towed vertically three times from the bottom to the water surface to collect samples for phytoplankton species diversity at each sampling location. $100 \mathrm{ml}$ concentrated sample was immediately preserved with $0.7 \mathrm{ml}$ Lugol's solution and after $1 \mathrm{~h} 2.5 \mathrm{ml}$ were added to sample.

Samples for phytoplankton abundance were collected at the surface, middle and bottom by using a 1-1 Van Dorn water sampler (the La MOTTE water sampler). The samples were immediately fixed as for diversity samples and placed in the dark cool box before analysis.

In the laboratory samples for diversity were examined using an inverted microscope at $400 \times$ magnification. Identification of phytoplankton species was done by using the available keys (Mosille 1984; John et al. 2002).

Samples for phytoplankton numerical abundance were sedimented for $48 \mathrm{~h}$. A $20 \mathrm{ml}$ concentrated sample, which remains in the bottom, was homogenized and $2 \mathrm{ml}$ of it was taken for observation under an inverted microscope at $400 \times$ magnification. Different species were counted as numbers of filaments and cells depending on the nature of the phytoplankton. At least 30 fields were mounted from one sample.

The phytoplankton numerical abundance was calculated by using the formula given in Greenberg and Clesceri (1992):

$$
=((\mathrm{C} * \mathrm{At} * \mathrm{v}) /(\mathrm{Af} * \mathrm{~F} * \mathrm{~V})) / \mathrm{V}_{1}
$$

where $\mathrm{C}=$ number of organism counted, At $=$ total area of bottom of settling chamber $\left(\mathrm{mm}^{2}\right), \mathrm{v}=$ volume of concentrated sample $(20 \mathrm{ml}), \mathrm{Af}=$ area of field $\left(\mathrm{mm}^{2}\right), \mathrm{F}=$ number of fields counted, $\mathrm{V}=$ volume of sample observed $(2 \mathrm{ml}), \mathrm{V}_{1}=$ Volume of the sedimented sample.

Shannon diversity index $\left(\mathrm{H}^{\prime}\right)$ (Shannon and Weaver 1949) was used to estimate macroinvertebrates and phytoplankton species diversity as follows:

$$
H=-\sum_{j=1}^{S} p_{i} \ln p_{i}
$$

where $\left(p_{i}\right)$ is the proportion of species $i$ relative to the total number of species, which is multiplied by the natural logarithm of this proportion $\left(\ln p_{i}\right)$. The resulting product is 
summed across species, and multiplied by -1 . Shannon's equitability $\left(E_{H}\right)$ was calculated as described by Magurran (1988) as follows; Equitability (Evenness) $=\mathrm{H} / \mathrm{Ln}$ S, where $\mathrm{H}=$ Diversity index, $\mathrm{S}=$ Natural logarithm of the number of taxa (S). Species richness was obtained by simply counting the number of species present.

\section{Results}

\section{Water quality}

Data relative to dissolved oxygen, $\mathrm{pH}$ and Secchi depth are reported on Table 1. There were small fluctuation of $\mathrm{pH}, \mathrm{DO}$ and Secchi depth among the sampling stations. Initially before the start of experiment at Shirati bay, the along the cages site had the mean depth of $7.0 \pm 0.0 \mathrm{~m}$. After stocking fish the mean depth slightly increased to $7.1 \pm 0.8 \mathrm{~m}$ showing no or less deposition of materials. The mean depth of the intermediate station was $11.0 \pm 0.0 \mathrm{~m}$ before the start of experiment and $11.0 \pm 1.4 \mathrm{~m}$ after the end of experiment. While the offshore water at the location selected as the control site maintained the mean depth of $12.0 \pm 0.0 \mathrm{~m}$ before and after the start of the experiment.

Almost all nutrient values indicated an increasing trend after the setting of the cages in both sites (along the cages, intermediate and control) except for Chl $a$. However highest increase was noted along the cages (Table 2).

\section{Phytoplankton diversity and abundance}

Cyanophytes dominates in terms of numerical abundance both before and after stocking of fish in cages (Table 3). For example before stocking of fish in cages this group contributed about $96.6 \%$ along the cages and $97.3 \%$ at the intermediate site. After stocking of fish in cages Cyanophytes increased along the cages (99.6\%), and slightly declined at the intermediate site (93.9 \%). Cyanophyte species that were common were Anabaena flosaquae, Anabaena spirodes, Merismopedia glauca, Aphanothece nidulans and Microcystis flos aquae.

The second largest group in terms of abundance was the diatoms which were higher at the intermediate site (5.6\%) and declined along the cages after stocking of fish (Table 3). The dominant diatoms were represented by Nitzschia acicularis and Synedra cunningtonii. Chlorophytes were poorly represented in terms of abundance and their abundance declined after stocking of fish in cages. However they were the second important group in terms of species richness after cyanophytes (Tables 3, 4).

\section{Macro-invertebrate diversity and abundance}

The main groups of macroinvertebrates encountered at Shirati bay were mollusks, insects and worms. Before stocking of fish in cages in the inshore of Shirati bay bivalves were dominating with the mean of $107 \pm 97.8$ (74\%) individuals $/ \mathrm{m}^{2}$ (Fig. 2). Gastropods made $16 \%$ of the invertebrate community, which was about $104.1 \pm 36.8$ individual $/ \mathrm{m}^{2}$. Both bivalves and gastropods constituted about $90 \%$ of the total abundance of the benthic population. While worms made $10 \%$ of the macro invertebrate abundance. A similar phenomenon was observed at the intermediate site, bivalves constituted $79 \%$ (295 individuals $/ \mathrm{m}^{2}$ ) followed by gastropods $14 \%$ (52 individuals $/ \mathrm{m}^{2}$ ) of the macro invertebrate abundance. Worms made $7 \%$ (26 individuals $/ \mathrm{m}^{2}$ ). Thus in both inshore (where the cages 


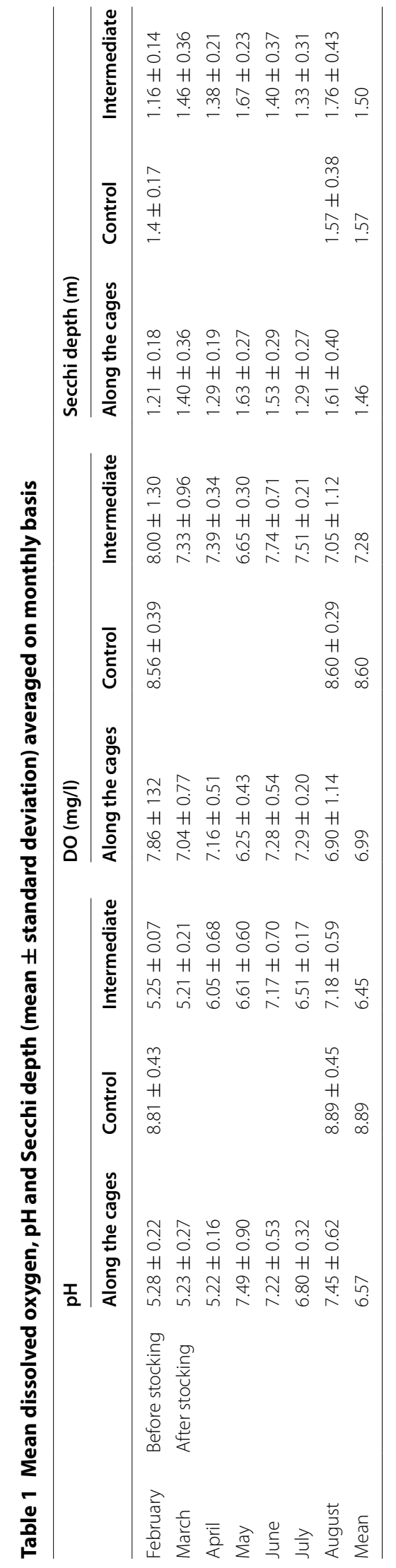




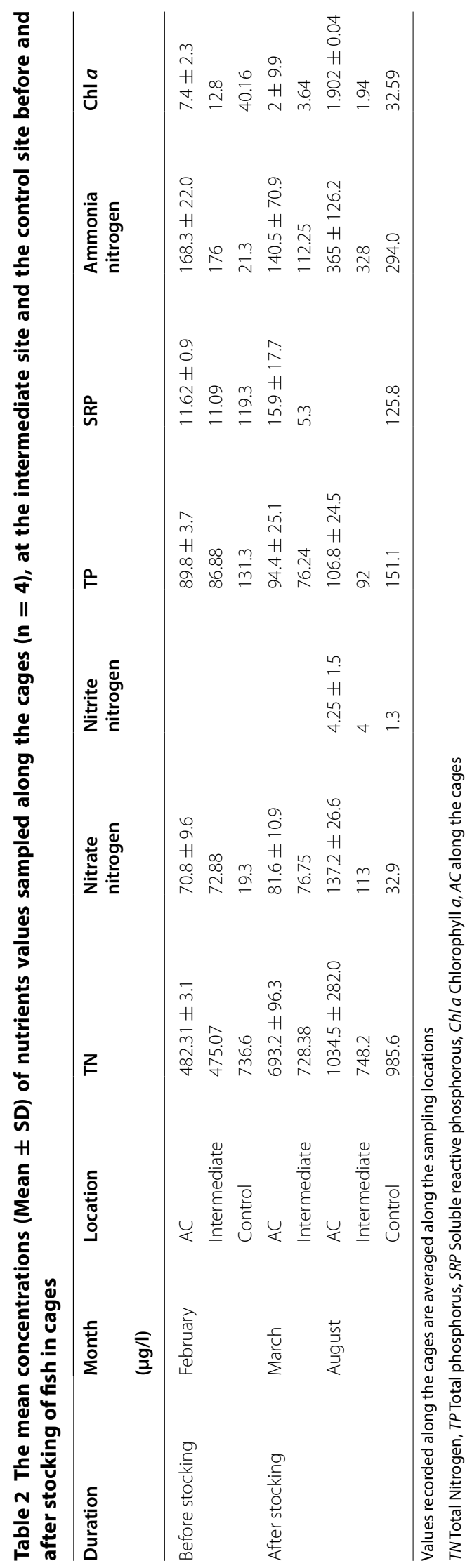


Table 3 Phytoplankton abundance (individuals/l) recorded at Shirati bay before and after the set of net cages

\begin{tabular}{lllllll}
\hline Taxa & \multicolumn{2}{l}{ Before stocking fish in cages } & & \multicolumn{2}{l}{ After stocking fish in cages } \\
\cline { 2 - 3 } & \multicolumn{1}{c}{ Along the cages } & Intermediate & & Along the cages & Intermediate \\
\hline Chlorophyceae & $30,688,359.8(0.9 \%)$ & $75,015,467.5(1.2 \%)$ & & $481,826.9(0.05 \%)$ & $782,968.8(0.5 \%)$ \\
Bacillariophyceae & $57,259,776.2(1.7 \%)$ & $94,205,470.8(1.5 \%)$ & $4,119,969.3(0.40 \%)$ & $8,492,199.5(5.6 \%)$ \\
Cyanophyceae & $3,247,559,634.7(96.6 \%)$ & $6,118,703,481.5(97.3)$ & $1,020,780,887.2(99.6 \%)$ & $141,898,028.8(93.9 \%)$ \\
Dinophyceae & $25,319,335.6(0.8 \%)$ & $0(0 \%)$ & $0(0 \%)$ & $0(0 \%)$ \\
Xanthophyceae & $401,522.4(0.01 \%)$ & $0(0 \%)$ & $0(\%)$ & $0(0 \%)$ \\
\hline
\end{tabular}

to be set) and intermediate, bivalves were dominating (Figs. 2, 3). However the highest abundance of bivalves was recorded at the intermediate site (Fig. 4).

After stocking fish in net cages bivalves community increased by $12 \%$ in the inshore waters along the cages and $7 \%$ at the intermediate site. During this time inshore waters along the cages had mean number of $468(86 \%)$ individuals $/ \mathrm{m}^{2}$, gastropods had the mean number of $87.9 \pm 46.0$ (11\%) individuals $/ \mathrm{m}^{2}$, and insects made $3 \%$ of the invertebrate abundance $\left(52.1 \pm 21.3\right.$ individual $\left./ \mathrm{m}^{2}\right)$. The intermediate site in the offshore waters also was dominated by bivalves. However there was a decline in number of bivalves at the intermediate site by about $11 \%$ after the set of cages. The mean abundance of bivalves was $97.6 \pm 44.5$ individuals $/ \mathrm{m}^{2}$ (68 \%), gastropods accounted for $27 \%$ of the intermediate site in the offshore waters $\left(78.1 \pm 36.8\right.$ individuals $\left./ \mathrm{m}^{2}\right)$, with a decline of about $13 \%$ after the set of cages. Insects were $5 \%$ of the whole invertebrate community (26 individuals $/ \mathrm{m}^{2}$ ) (Fig. 5).

\section{Benthic organism distribution by taxon}

Initially before stocking fish in cages, gastropod of the viviparidae family Bellamya costulata was the only specie of gastropod found at Shirati bay. The highest abundance was found in the inshore waters where the cages were set $\left(69\right.$ individuals $/ \mathrm{m}^{2}$ ), the intermediate site had the least abundance ( 52 individuals $/ \mathrm{m}^{2}$ ).

After stocking fish in cages species richness of gastropods increased (B. costulata, Bellamya unicolor and Melanoides tuberculata). However B. costulata increased at both along the cages $\left(121 \pm 39.8\right.$ individuals $\left./ \mathrm{m}^{2}\right)$, and intermediate site $\left(104\right.$ individuals $\left./ \mathrm{m}^{2}\right)$. Melanoides tuberculata $\left(95 \pm 15.0\right.$ individuals $/ \mathrm{m}^{2}$ ) was the only species encountered along the cages. Higher abundance of $B$. unicolor was recorded at the intermediate site (52 individuals $\left./ \mathrm{m}^{2}\right)$ than those along cages $\left(17 \pm 15.0\right.$ individuals $\left./ \mathrm{m}^{2}\right)$.

Bivalves were more diverse and abundant before and after stocking fish in cages with Sphaerium nyansa, Sphaerium stuhlmanni, Coelatura alluaudi and Coelatura monceti dominating. Before stocking S. nyansae was higher in abundance at the intermediate site $\left(651\right.$ individuals $\left./ \mathrm{m}^{2}\right)$ than in the inshore along the cages $\left(95\right.$ individuals $\left./ \mathrm{m}^{2}\right)$. After stocking higher abundance was recorded in the inshore along the cages (1293 individuals $/ \mathrm{m}^{2}$ ), while the intermediate had 78 individuals $/ \mathrm{m}^{2}$. Before stocking higher abundance of $S$. stuhlmanni was recorded along the cages (139 individuals $/ \mathrm{m}^{2}$ ) than the intermediate site (104 individuals $/ \mathrm{m}^{2}$ ). After stocking there was an increase in abundance of S. stuhlmanni with 382 individuals $/ \mathrm{m}^{2}$ along the cages and 156 individuals $/ \mathrm{m}^{2}$ at the intermediate site. 
Table 4 Phytoplankton species encountered along the cages and at the intermediate site ( $X$ = phytoplankton encountered before stocking fish in cages, $+=$ phytoplankton encountered after stocking fish in cages, and $\mathrm{X}+=$ phytoplankton encountered before and after stocking fish in cages)

\begin{tabular}{|c|c|c|}
\hline Chlorophyceae & Along the cages & Intermediate \\
\hline Ankistrodesmus falcatus & $x$ & $x$ \\
\hline Ankistrodesmus setigera & $x$ & $x$ \\
\hline Chordatella subsala var. citriformis & $x$ & \\
\hline Coelastrum cambricum var. nasutam & $x$ & $x$ \\
\hline Coelastrum microporum & & + \\
\hline Coelastrum reticulatum & $x$ & \\
\hline Dimorphococcus lunatus & $x$ & \\
\hline Kirchneriella contorta & $x$ & $x$ \\
\hline Oocystis lacustris & $x$ & $x$ \\
\hline Oocystis solitaria & $x$ & $x$ \\
\hline Pediastrum duplex & & $x$ \\
\hline Pediastrum simplex var. microporum & $x$ & $x$ \\
\hline Pediastrum simplex var. duodenarium & $x_{+}$ & \\
\hline Pediastrum simplex var. radians & + & \\
\hline Scenedesmus sp. & $x$ & \\
\hline Staurastrum gracile var. nyassae & $x$ & $x$ \\
\hline Staurastrum limneticum & $x$ & \\
\hline Staurastrum sp. & $x$ & \\
\hline \multicolumn{3}{|l|}{ Bacillariophyceae } \\
\hline Aulacoseira granulata & + & + \\
\hline Coscinodiscus rudolfi & + & \\
\hline Cyclotella kützingiana & $x$ & \\
\hline Navicula sp. & & + \\
\hline Nitzschia acicularis & $x+$ & $x+$ \\
\hline Rhizosolenia victoriae & + & + \\
\hline Surirella biseriata & $x$ & \\
\hline Surirella fullebornii var. elliptica & $x$ & \\
\hline Synedra cunningtonii & $x+$ & $x+$ \\
\hline Synedra ulna & $x_{+}$ & + \\
\hline \multicolumn{3}{|l|}{ Cyanophyceae } \\
\hline Anabaena flos aquae & $x+$ & $x+$ \\
\hline Anabaena spirodes & $x+$ & $x+$ \\
\hline \multicolumn{3}{|l|}{ Anabaenopsis sp. } \\
\hline Aphanothece nidulans & & $x+$ \\
\hline Chroococcus limneticus & $x+$ & $x$ \\
\hline Chroococcus sp. & & + \\
\hline Chroococcus turgidus & $x$ & + \\
\hline Coelosphaerium sp. & & $x$ \\
\hline Cylindrospermopsis curvispora & & $x$ \\
\hline Cylindrospermopsis philippinensis & & $x$ \\
\hline Merismopedia glauca & $x$ & + \\
\hline Merismopedia tenuissima & $x$ & $x$ \\
\hline Microcystis aeruginosa & $x$ & $x$ \\
\hline Microcystis flos-aquae & $x+$ & $x+$ \\
\hline Planktolyngbya circumcreta & $x+$ & $x+$ \\
\hline Planktolyngbya contarta & $x$ & \\
\hline Planktolyngbya limnetica & $x+$ & $x+$ \\
\hline
\end{tabular}


Table 4 continued

\begin{tabular}{|c|c|c|}
\hline Chlorophyceae & Along the cages & Intermediate \\
\hline Planktolyngbya mertensiana & $x$ & \\
\hline Planktolyngbya tallingii & $x+$ & $x+$ \\
\hline Planktolyngbya undulata & $x$ & $x$ \\
\hline Pseudoanabaena spp. & $x$ & $x$ \\
\hline Romeria sp. & $x$ & \\
\hline \multicolumn{3}{|l|}{ Dinophyceae } \\
\hline Glenodinium sp. & $x$ & \\
\hline Ceratium limneticus & $x$ & \\
\hline \multicolumn{3}{|l|}{ Xanthophyceae } \\
\hline Ophiocytium cochleare & $x$ & \\
\hline
\end{tabular}

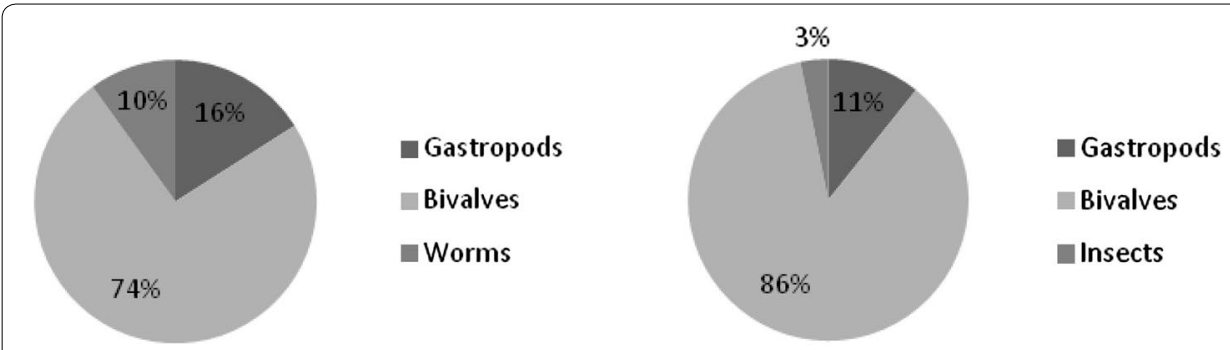

Fig. 2 Percentage composition of benthic macro invertebrate groups sampled along the cages before and after stocking fish, Shirati bay

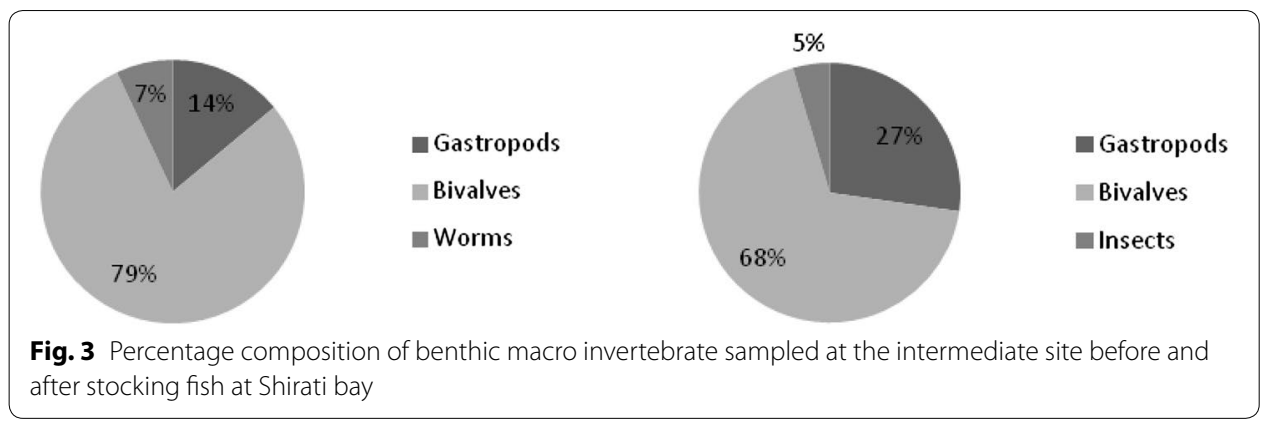

Before stocking C. alluaudi (35 individuals $/ \mathrm{m}^{2}$ ) was only found along the cages in the inshore waters. After stocking C. alluaudi was found at both along the cages (78 individuals $/ \mathrm{m}^{2}$ ) and the intermediate site (104 individuals $\left./ \mathrm{m}^{2}\right)$. Before stocking higher abundance of $C$. monceti were found at the intermediate site $\left(130\right.$ individuals $\left./ \mathrm{m}^{2}\right)$ than the along the cage site (52 individuals $/ \mathrm{m}^{2}$ ). After stocking C. monceti abundance increased along the cages to 121 individuals $/ \mathrm{m}^{2}$, while the intermediate site remained the same (130 individuals $/ \mathrm{m}^{2}$ ).

Insects of the class heptageniidae were only found along the cages after stocking fish in cages with 35 individuals $/ \mathrm{m}^{2}$. While chaoborus larvae were also only found after stocking along the cages ( 35 individuals $\left./ \mathrm{m}^{2}\right)$ and the intermediate site $\left(26\right.$ individuals $\left./ \mathrm{m}^{2}\right)$. 


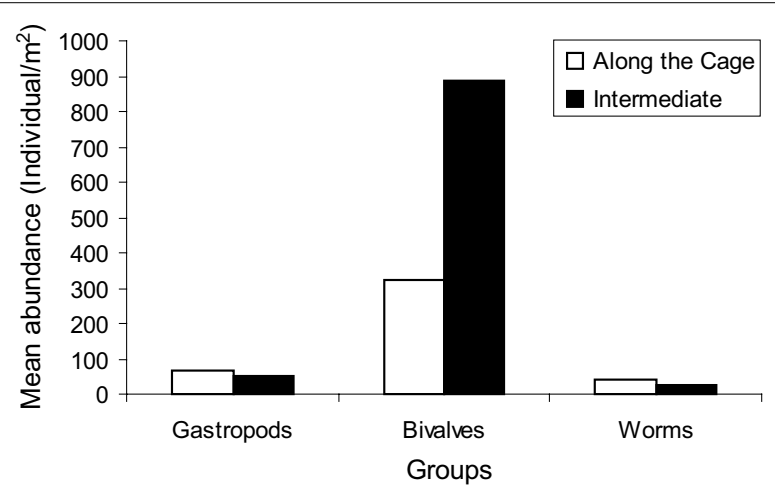

Fig. 4 Mean abundance of different macro invertebrate groups before stocking fish in net cages at Shirati bay

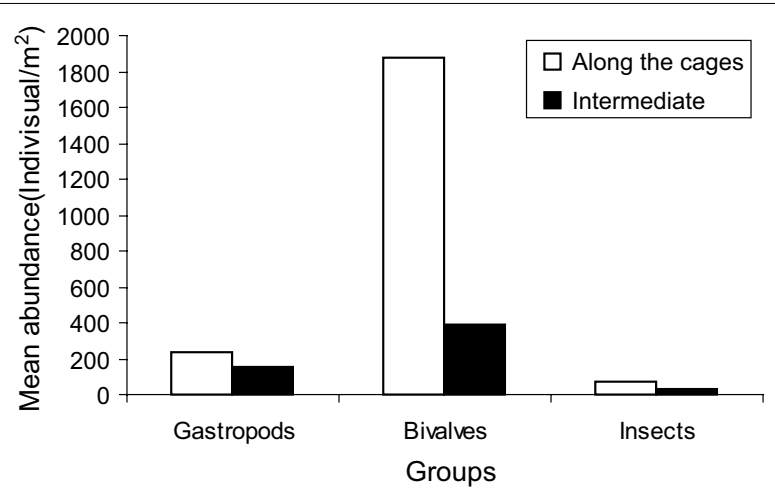

Fig. 5 Mean abundance of different macro invertebrate groups after the start of cage farming activities at Shirati bay

\section{Discussion}

Fish farming in the lakes, is expected to produce waste with a high concentration of $\mathrm{N}$ and P released in solute form into the water column (Neofitou and Klaoudatos 2008). However, previous studies dealing with the analysis of plankton response to fish farming showed no significant difference between cages and control site (Pitta et al. 1999). Furthermore, several studies failed to establish a relationship between farm waste and phytoplankton growth, even when large inorganic nutrient inputs were recorded (Beveridge 1996). This study reports an increase in $\mathrm{N}$ and $\mathrm{P}$ in the inshore along the cages over the period of the cage trials. The offshore area which we considered as the control also experienced the same increase of $\mathrm{N}$ and $\mathrm{P}$, although its increase was minimal compared to the inshore waters and the intermediate site. The increase in nutrient in the inshore along the cages may have been caused by the overall activities in the cages such as feeding. Other reason may be due to reduction in water movement caused by the presence of fish cages. This suggestion was verified by Iwama (1991), who reported reduction in water current velocity by $65 \%$ inside the fish cages, mainly due to physical water obstruction by nets and organisms attached to them. In addition, other sources may have come from agricultural activities in the catchment which is reported to be the major contributor of N and P loading in the lake (Guildford and Hecky 2000; Scheren 
et al. 2000; Ngupula et al. 2012). After stocking of fish in cages the reported values of TN, Nitrate and Ammonia of this study were higher than previous findings in the same site. For instance results from TAFIRI 2005 technical reports show low values of $\operatorname{TN}(861.1 \pm 176.0 \mu \mathrm{g} / \mathrm{l})$, Nitrate $(26.1 \pm 9.6 \mu \mathrm{g} / \mathrm{l})$ and Ammonia $(157.6 \pm 192.8 \mu \mathrm{g} / \mathrm{l})$. However increase in nitrate concentrations is mostly linked to terrestrial run off (Talling and Talling 1965). Furthermore our findings for TP, SRP and Chlorophyll $a$ were lower than the previous study at the same site as shown by the TAFIRI (2005) technical reports $(\mathrm{TP}=141.2 \pm 14.0 \mu \mathrm{g} / \mathrm{l}$, Chlorophyll $a=36.4 \pm 5.4 \mu \mathrm{g} / \mathrm{l}$ and SRP $=122.6 \pm 4.6 \mu \mathrm{g} / \mathrm{l})$. The Chlorophyll $a$ values reported in this study and from the TAFIRI technical reports agree with Sitoki et al. (2010) who reported the chlorophyll $a$ values of Lake Victoria rarely exceeds 30 and $50 \mu \mathrm{g} / \mathrm{l}$ in inshore and offshore respectively. Furthermore the chlorophyll $a$ values we report on both stations lie well within the range of values given by Huszar et al. (2006) who obtained the mean values of $34.2 \mu \mathrm{g} / \mathrm{l}$ from 192 tropical lakes. From these findings it can be noted that the observed dynamics in $\mathrm{N}$ and $\mathrm{P}$, Chlorophyll a mainly caused by seasonal land fluxes and phytoplankton uptake rather than the cage activities alone.

Fish farming enriches the water column with dissolved organic and inorganic nutrients and leads to a reduction in DO, both in the vicinity of the fish farm and at the site of remineralization of the waste products (Beveridge 1996; Mente et al. 2006). In this study the effect of nutrient discharge on DO was not pronounced. Our study report quite good dissolved oxygen level and Secchi disk reading throughout the study period, both along the cages, at the intermediate and control sites. These findings concur with Neofitou and Klaoudatos (2008), who found no effect of nutrient increase on DO in fish cages. The depth of the station also almost remained constant with minimal variations showing that there was no or less deposition of uneaten feeds.

The predominance of Cyanophytes at the Shirati bay may be attributed by the high concentrations of nutrients (Nitrate, ammonia and phosphorous). Eutrophic condition of the lake water has a tendency of allowing fewer species to grow faster and abundantly, this in turn permits a lower number of species to coexist (Moss 1998). This can explain the reasons of decline of species richness and diversity after establishment of cage culture activities, but the abundances of which were very high (Tables 3, 4, 5). The fact that most of the dissimilarities observed among the stations show changes in phytoplankton abundance rather than increase of typical species implies that there is relatively low intensity of disturbance caused by cage culture activities at the bay.

Table 5 Shannon diversity index, species richness and equitability (evenness) of phytoplankton species within the cage area and at the intermediate site recorded before and after stocking of fish in cages

\begin{tabular}{|c|c|c|c|c|}
\hline & \multicolumn{2}{|c|}{ Within the cage area } & \multicolumn{2}{|c|}{ Intermediate } \\
\hline & Before & After & Before & After \\
\hline Richness & 41 & 15 & 27 & 17 \\
\hline Diversity index & 1.268 & 0.476 & 1.435 & 1.818 \\
\hline Equitability & 0.341 & 0.176 & 0.435 & 0.642 \\
\hline
\end{tabular}

Generally, species richness decreased in both sites while diversity index decrease along the cage and increase at intermediate site. Equitability declined after stocking fish in cages within the cage area and increased at the intermediate site after stocking fish in cages 
Aquatic macro invertebrates are used in pollution studies due to their typical abundance, relatively immobile and they can tolerate a wide range of pollution. The combination of macro invertebrate, phytoplankton and water quality studies can give a good explanation about the status of pollution of a particular water body. This study reports that even before stocking fish in net cages at Shirati bay, high abundance of mollusks (bivalves and gastropods) were recorded at both inshore (along the cages) and offshore

Table 6 Mean abundance (individuals $/ \mathrm{m}^{2}$ ) of macro invertebrates species at the intermediate and along the cages encountered before the start of cage farming activities at Shirati bay

\begin{tabular}{lll}
\hline Microinvertebrates & Along the cage & Intermediate \\
\hline $\begin{array}{l}\text { Gastropods } \\
\text { Bellamya costulata }\end{array}$ & 69 & 52 \\
Bivalves & & \\
Sphaerium nyansae & 95 & 651 \\
Sphaerium stuhlmanni & 139 & 104 \\
Caelatura alluaudi & 35 & 0 \\
Caelatura monceti & 52 & 130 \\
Worms & 43 & 26 \\
\hline
\end{tabular}

Table 7 Mean abundance (individuals $/ \mathrm{m}^{2}$ ) of macro invertebrates species at the intermediate and along the cages encountered after the start of cage farming activities at Shirati bay

\begin{tabular}{lll}
\hline Macroinvertebrates & Along the cages & Intermediate \\
\hline Gastropods & 17 & 52 \\
$\begin{array}{l}\text { Bellamya unicolor } \\
\text { Bellamya costulata }\end{array}$ & 121 & 104 \\
Melanoides tuberculata & 95 & 0 \\
Bivalves & & \\
Sphaerium nyansae & 1293 & 78 \\
Sphaerium stuhlmanni & 382 & 156 \\
Caelatura alluaudi & 78 & 104 \\
Caelatura monceti & 121 & 52 \\
Insects & & 0 \\
Ephemeroptera & 0 & 0 \\
Heptageniidae & 35 & 26 \\
Chaoborus larvae & 35 & \\
\hline
\end{tabular}

Table 8 Shannon diversity index, species richness and equitability (evenness) of benthic macro invertebrate species within the cage areas and at the intermediate site recorded before and after the set of cages

\begin{tabular}{|c|c|c|c|c|}
\hline & \multicolumn{2}{|c|}{ Along the cage } & \multicolumn{2}{|c|}{ Intermediate } \\
\hline & Before & After & Before & After \\
\hline Richness & 6 & 9 & 5 & 7 \\
\hline Diversity index & 1.317 & 1.044 & 0.791 & 1.604 \\
\hline Equitability & 0.735 & 0.475 & 0.491 & 0.825 \\
\hline
\end{tabular}


(control), but the highest abundance being at the inshore (Table 6). After stocking fish in net cages an increase in bivalves and gastropods was noted at both the inshore and at the intermediate site, the highest being at the inshore along the cages (Table 7). Unlike Apostolaki et al. (2007), who carried out a similar study in seaweeds farms reported a peak in macrofauna at the distance of $40 \mathrm{~m}$ from the cages. Like Apostolaki et al. (2007), species numbers showed little variability between the stations, and an increase in diversity index with increasing distance from the farm (Table 8). While the abundance of worms and insects were very low and even disappeared after stocking of fish in cages. The increase in gastropods and bivalves may be caused by the presence of organic materials that resulted from uneaten feeds and detritus materials which could have attracted both the gastropods and bivalves to obtain their source of food. Gastropods are reported to be the major browsers that feed on the organic cover of the bottom while bivalves are the filter feeders in the same bottom organic cover (Mavuti and Litterick 1991). Insects, gastropods and worms are reported to be more tolerant to high organic pollution (Ngupula et al. 2012).

\section{Conclusions}

Despite the fact that our results indicated no consistent environmental changes at the cage sites. The localized water quality dynamics observed are a common phenomenon in cage culture and does not explain any environmental problem. Generally Lake Victoria is ranked as hyper-eutrophic lake (OECD 1982). Therefore, caution should be taken when authorizing cage culture in the lake so as not to compromise the already deteriorated water quality and impair the ability of the lake to provide benefits sustainably to the communities whose livelihood depend on it. Thus, we suggest a proper site selection and continuous environmental monitoring be an essential component when considering introduction of fish cage culture in Lake Victoria.

\section{Authors' contributions}

BBK is the main author, participated in designing the research, data collection, analysis and drafted this manuscript. PN participated in designing the research, data collection and reviewing manuscript. RK participated in designing the research, data analysis and reviewing manuscript. GWN and CNE participated in data collection and analysis. CAM participated in data collection and drawing a map. All authors read and approved the manuscript.

\section{Author details}

${ }^{1}$ Tanzania Fisheries Research Institute (TAFIRI), P. O. Box 475, Mwanza, Tanzania. ${ }^{2}$ Tanzania Fisheries Research Institute (TAFIRI), P. O. Box 46, Sota, Shirati, Mara region, Tanzania.

\section{Acknowledgements}

This study was financially supported by the Association for Strengthening Agricultural Research in Eastern and Central Africa (ASARECA) research funds. We are highly appreciate the cooperation from TAFIRI staff and the Water quality laboratory- Igogo for helping us with the chemical analysis of our water samples.

\section{Compliance with ethical guidelines}

\section{Competing interests}

The authors declare that they have no competing interests. The study was financed by ASARECA project which ended in 2013. One among many objectives of ASARECA was to transfer cage fish farming technology to local fish farmers in the Lake Victoria region. The publication of this manuscript will help policy makers to make good decisions before introducing fish cage farming in lake Victoria. The processing of this manuscript is not financed by any organization. The publication of this manuscript will have no negative effect to the funding organization. We declare that we do not have any share or stock that will gain or lose financially after the publication of this manuscript. Furthermore we do not apply any patent related to the manuscript. 


\section{References}

Apostolaki ET, Tsagaraki T, Tsapakis M, Karakassis I (2007) Fish farming impact on sediments and macrofauna associated with seagrass meadows in the Mediterranean. Estuar Coast Shelf Sci 75(2007):408-416

Beveridge M (1996) Cage aquaculture. Fishing News Books, Oxford, p 346

Brown DS (1994) Fresh water snails of Africa and their medical importance, 2nd edn. Taylor \& Francis, London, p 609 FAO (2004) FAO Regional Technical Expert Workshop on Cage culture in Africa, Entebbe

Greenberg AE, Clesceri LS (1992) Standard methods for the examination of water and waste water, 18th edn. American Public Health Association, Washington, DC, pp 10-137

Guildford SJ, Hecky RE (2000) Total nitrogen, total phosphorus and nutrient limitation in lakes and oceans: is there a common relationship? Limnol Oceanogr 45:1213-1223

Huszar VLM, Caraco NF, Roland F, Cole J (2006) Nutrient-chlorophyll relations in tropical-subtropical lakes: do temperate models fit? Biogeochemistry 79:239-250

Iwama Gl (1991) Interactions between aquaculture and the environment. Crit Rev Env Control 21:177-216

John DM, Whitton BA, Brook AJ (2002) The freshwater algae flora of the British Isles: an identification guide to freshwater and terrestrial algae. Cambridge University Press, Cambridge, $\mathrm{p} 702$

Magurran AE (1988) Ecological diversity and its measurement. Princeton University Press, Princeton, p 192

Mandahl-Barth G (1958) Intermediate hosts of schistosoma; African Biomphalaria and Bulinus. Monograph 37. World Health Organization, Geneva

Mandahl-Barth G (1973) A field guide to African freshwater snails. 2. East African species. Danish Bilharziasis Laboratory, Charlottenlund

Mandahl-Barth G (1988) Studies on African freshwater bivalves. Danish Bilharziasis Laboratory, Charlottenlund Masser M (2008) What is cage culture? SRAC publication No. 160

Mavuti KM, Litterick MR (1991) Composition, distribution and ecological role of zooplankton community in Lake Victoria, Kenya waters. Verhandlungen Internationale Vereinigungfür Limnologie 24:1117-1122

Mente E, Pierce GJ, Santos MB, Neofitou C (2006) Effect of feed and feeding in the culture of salmonids on the marine aquatic environment: a synthesis for European aquaculture. Aquacult Int 14:499-522

Mosille O (1984) Phytoplankton species of Lake Victoria. Reports from the Haplochromis ecology survey team (HEST) operating in the Mwanza area of Lake Victoria. Zoologisch laboratorium, Morphology Department, Leiden University, Leiden, The Netherlands

Moss B (1998) Ecology of freshwaters, man and medium, past to future, 3rd edn. University Press, New York

Neofitou Nikos, Klaoudatos S (2008) Effect of fish farming on the water column nutrient concentration in a semienclosed gulf of the Eastern Mediterranean. Aquac Res 2008(39):482-490

Ngupula GW, Kayanda R (2010) Benthic macrofauna community composition, abundance and distribution inthe Tanzanian and Ugandan inshore and offshore waters of Lake Victoria. Afr J Aquat Sci 35(2):185-192

Ngupula GW, Ezekiel CN, Kimirei IA, Mboni E, Kashindye BB (2012) Physical and chemical characteristics of the Tanzanian inshore and offshore waters of Lake Victoria in 2005-2008. Afr J Aquat Sci 37(3):339-345

Organisation for Economic Cooperation and Development (OECD) (1982) Eutrophication of waters: monitoring, assessment, and control. OECD, Paris 154

Pitta P, Karakassis I, Tsapakis M, Zivanovic S (1999) Natural vs. mariculture induced variability in nutrients and plankton in the eastern Mediterranean. Hydrobiologia 391:181-194

Scheren PAGM, Zanting HA, Lemmens AMC (2000) Estimation of water pollution sources in Lake Victoria, East Africa: application and elaboration of the rapid assessment methodology. J Environ Manage 58:235-248

Shannon CE, Weaver W (1949) The mathematical theory of communication. University of Illinois Press, Urban, IL

Sitoki L, Gichuki J, Ezekiel CN, Wanda F, Mkumbo OC, Marshal BE (2010) The environment of lake Victoria (East Africa): current status and historical changes. Internat Rev Hydrobiol 95(3):209-223

TAFIRI (2005) Bottom trawl report Technical report, Lake Victoria, Tanzania. IFMP/TAFIRI technical report (September, 2005)

Talling JF, Talling IB (1965) The chemical composition of African lake water. Inaternationale Revue der Gesamten Hydrobiologie 50:421-463

\section{Submit your manuscript to a SpringerOpen ${ }^{\circ}$ journal and benefit from:}

- Convenient online submission

- Rigorous peer review

- Immediate publication on acceptance

- Open access: articles freely available online

- High visibility within the field

- Retaining the copyright to your article

Submit your next manuscript at $\boldsymbol{s p r i n g e r o p e n . c o m ~}$ 